

\title{
INVESTIGATING THE RELATIONSHIP BETWEEN TRANSFORMATIONAL LEADERSHIP STYLE AND ORGANIZATIONAL IDENTITY OF FACULTY MEMBERS IN THE STATE UNIVERSITIES OF WEST AZERBAIJAN PROVINCE, IRAN
}

\author{
Ali Pourmahmoud Hesar*, Mir Mohammad Seyed Abbaszadeh, \\ Alireza Ghalei and Hassan Ghalavandi
}

\author{
Urmia University, Department of Educational Administration, \\ $11 \mathrm{~km}$ SERO Road, Urmia, Iran
}

(Received 22 April 2017; accepted 17 May 2018)

\begin{abstract}
The aim of this research was to investigate the relationship between transformational leadership style and organizational identity of faculty members in the state universities of West Azerbaijan Province, Iran. This research was a descriptive and correlational study. The statistical population of the research included all faculty members of these universities whose number was 765 at the time the research was conducted. Using Morgan table and stratified random sampling method, 256 persons were selected as the statistical sample of the research. 300 questionnaires were distributed among which 283 were returned, the final data analysis was conducted for 283 persons using SPSS and LISREL software. Standard multifactor leadership questionnaire (MLQ) and Cheney's organizational identity questionnaire (1982) were used to collect data regarding transformational leadership and organizational identity, respectively. The reliability of the questionnaires was calculated to be 0.96 and 0.85 , respectively, using cronbach's alpha coefficient. Hypothesis and assumed relationships between variables in the proposed theoretical model were investigated using regression analysis and structural equation model. The results obtained from this research showed that there was a positive and meaningful relationship between transformational leadership style, its variables and organizational identity of faculty members in the state universities of West Azerbaijan Province, Iran $(p<0.01, r=0.26)$. In addition, the statistical results obtained from this research indicated a positive and the direct effect of transformational leadership style on organizational identity of faculty members. The results also showed that, among different components of transformational leadership style, intellectual stimulation had the strongest effect on organizational identity of faculty members.
\end{abstract}

Keywords:leadership, transformational leadership, identity, faculty

*Corresponding author:a.pourmahmoud@urmia.ac.ir

DOI: $10.5937 /$ sjm14-13786 


\section{INTRODUCTION}

Managers' leadership style in organizations, particularly in educational organizations such as schools, universities and other higher educational institutions is one of the most important organizational factors affecting the efficiency and performance of these active and dynamic social systems. Application of effective leadership styles in above mentioned institutions significantly increases the effectiveness and influence of leaders on the behaviors and attitudes of their staff, and creates fundamental transformations in the structure and different aspects of these institutions. By increasing the speed of environmental changes and the more complicated the situations become, the importance of this issue is also increased and the application of effective leadership styles in educational institutions also takes on strategic aspect. The positive effects indicated in numerous researches conducted in this field also strongly support this claim.

The results obtained from a research in public universities of Kenya, showed that, there was a meaningful and inverse relationship between the leadership styles of the managers and their academic staff's tendency to remain or leave in these universities. Therefore, while the role of the leaders seems important in the tendency to stay or leave service in organizations, the leadership style of the managers plays a key role in this regard (Muceke Ng'ethe, 2012).

In the recent years, the roles of academic leaders have been identified as crucial for the success of any higher education academic institutions. There is a relationship between the leadership styles of academic leaders with organizational performance and the educational achievement of the Universities. Thus, it is important to apply appropriate leadership styles that can enhance organizational performance of higher education systems (Mohd Nasir et al., 2014).

Universities and institutions of higher education need to be susceptible to the issue of leadership practices and concepts as a major issue is confronting their Managers. In these organizations, president's competencies in knowledge, leadership skills, and technical expertise are necessary to ensure the successful completion of a transformational effort. Also, presidents must have the individual quality of commitment demonstrated with passion, intensity, persistence which will supply the energy to momentum, and motivate and stimulate the stakeholders to strive toward a group effort (Basham, 2010).

Today, universities and higher educational institutions are active in turbulent, complex and constantly changing environments. The inherent structure and nature of these educational systems require that they act as living organisms and actively and dynamically interact with their surroundings. Also, under some circumstances they require efficient and transformational leaders and staff with integrated, loyal and committed organizational identities to the values and goals of the organization. Transformational leaders in these organizations could play a major and constructive role in the formation and corroboration of the organizational identities of faculty members. Achieving greater feeling of organizational identity among faculty members could also increase their motivation and organizational commitment which could significantly increase their optimal performance and productivity. This is an important issue 
which generally, its necessity is not seriously considered by senior managers and key decision makers of these organizations however it might cause lots of damages to their structures, Content of goals and various programs. Therefore, the issue of leadership and development of leadership abilities in universities and higher educational institutions as well as high quality and productivity of human resources can be considered among important issues and fundamental challenges facing them.

It seems that among new leadership styles, due to its superior features, transformational leadership offers better possibilities for the managers of universities and higher educational institutions for favorable performance and facing challenges and complications of the modern world and provides the leaders of these dynamic and effective social systems with new routes of growth, prosperity and transformation.

In the recent years, a significant amount of research has been conducted on leadership behavior. Academics and managers have increasingly focused on emotional and symbolic aspects of leadership. These aspects are within a type of leadership which is called neo-charismatic theories or more simply transformational theories. This new leadership theory emphasizes on charismatic leaders with strong emotional attraction among the followers (Ergenelia et al., 2007).

Transformational or charismatic leadership theory has been developed and extended since late 1980s and different versions of it have been proposed by authors especially Bass. Transformational leadership theory is totally about leaders who create positive changes among their followers and therefore take care of each other's benefits and act in the interests of the group as a whole.
Transformational leadership style is among novel and effective styles in most organizations and has always been considered as one of the most prominent styles in leadership theory studies. Many researches have been conducted regarding the effectiveness of the leaders and leadership style and the results obtained from this study showed that the application of transformational leadership style has made the leaders more efficient and effective (Barling et al., 2000).

The aim of this research was to investigate the relationship between transformational leadership style and organizational identity among faculty members in the state universities of West Azerbaijan Province considering theoretical foundations, characteristics and key concepts of transformational leadership as well as the results obtained from previous works. Therefore, the main question in this research was that whether there was a meaningful relationship between transformational leadership style and organizational identity of faculty members in the state universities of West Azerbaijan Province. This research was based on the assumption that the behaviors of the managers in the investigated universities to some extent had the characteristics of transformational leadership style and the effectiveness of transformational leadership style in the formation of organizational identity among faculty members and the presence of a possible relationship between these two parameters was investigated based on this assumption. 


\section{A REVIEW OF THE THEORETICAL FOUNDATIONS}

\subsection{Transformational leadership style}

Transformational leadership style is one of the important theoretical frameworks which were presented by Burns (1978) and Bass (1985). In recent years also much interest has been in the application of a novel managerial pattern of transformational leadership such that only during 1990-1995 more than one hundred thesis and research works have been conducted in different universities all over the world have investigated the concept of transformational leadership. In 1990 Bass stated that leaders can guide their followers to achieve more than expected performances using behavioral characteristics of transformational leadership (Humphreys \& Einstein, 2003).

The expression "transformational leadership" was first coined by Danton (1973). However, this expression became famous when the classics such as Burns used it. The concept of transformational leadership was once again presented by James McGregor Burns in his descriptive research on political leaders, but its use was extended to organizational psychology and management with more variations by Bass and Avolio. Bass and Avolio extended the idea and concept of Burns on leadership and a new concept of transformational leadership was created (Jung \& Sosik, 2002). The main assumption of transformational leadership theory is that, transformational leaders motivate and encourage their followers to perform more than expected and go beyond the programs (Krishnan, 2005).

The results obtained from different research works have indicated that transformational leaders inspire and encourage their followers to achieve extraordinary results and by creating motivation and self-confidence, they help their followers to better distinguish and gain a better understanding of the goals of the organization. Also, by providing more authority and independence for the staff, they improve performance and increase efficiency (Bass et al., 2003).

A transformational leader is basically a person who cares about the stresses, anxieties and growth needs of each and every follower. Transformational leaders change the awareness and consciousness of their followers regarding different issues by helping them in a way that they can find new solutions to their old issues and they are surely able to encourage and excite their flowers to achieve group goals (Robbins \& Coulter, 2007).

Transformational leaders facilitate the process of changing into people and organizations. These leaders provide an attractive, attractive, realistic and believable provision of future regarding the existing conditions for their organization or unit and cause successful execution of these changes in the organization.

It is believed that, transformational leaders had concerns about transformations in the organization and among its personnel and affect the organization staff and their followers such that they can redirect their interests toward the group goals and intensify their commitment to the provisions of the organization. These leaders search transformation in the values and selfconceptions and direct them to higher levels of needs and wishes.

Based on the ideas of Pawar \& Eastman, the effectiveness of a transformational leader is a result of three factors: relative position of the organization in the continuum of 
organizational acceptance (change acceptance), the degree of compliance of transformative process required for the success of the organization and transformative leadership process under execution in the organization and the ability of transformational leaders in the implementation of a suitable flexible transformational process assures that the organization has the capability of dynamic activity or quick response to competition and changing conditions and therefore this creates or retains the existing competitive advantage. A transformational leader induces the change in the whole organization and creates a vision for both managers and staff (Beugré et al., 2006).

According to Burns (1978) idealized influence, inspirational motivation, intellectual stimulation and individual considerations are the four main points of transformational leadership (Fasola et al., 2013).

In a research, Warrilow (2009) identified the four major elements of transformational leadership style. These four elements are:

Idealized influence or charisma: a degree of behavior that the leader shows with admirable solutions which cause the followers to believe that their leader is a person with a bright set of beliefs, opinion and values and acts as an example for the followers.

Inspirational motivation: a degree indicating the vision regarding what the leader wants to be revised and inspires his followers by being optimistic about future goals and at the same time provides a means for their current duties.

Intellectual stimulation: a degree which the leader challenges the assumptions and stimulates and encourages the creativity of his followers by providing a framework for them (to see how to communicate with the leader, organization, each other and their goal) so that they can overcome the hardships and barriers on their way in a creative manner.

Individual considerations: a degree that determines the extent that the leader cares about the individual needs of each of the followers and shows his reaction as a trainer or coach based on respect and appreciation for each person for their contribution in a team work. Addressing these individual needs and increasing respectful attention by the leader is in fact a necessity for the selfevaluation and self-actualization of team members and is a source of inspiration in their way to bigger prosperity and growth (Odumeru \& Ifeanyi, 2013).

\subsection{Organizational Identity}

Organizational identity is among the concepts that have attracted the attention of the researchers in the recent years, especially in the field of behavioral science; organizational psychology and studies regarding the organizations and many researches have been conducted in this field.

Theory of organizational identity was essentially developed based on social identity theory. The theory of social identity was first introduced and developed by Tajfel and Turner in 1970 and 1980. This theory introduces the concept of social identity as a way in which the behavior is described among a group and points to the feeling that a person gets by seeing himself as a part of a social group (Tuner \& Reynolds, 2010). In social identity theory an organization is considered as a social class with certain properties related to the people who are members of it.

Organizational identity was first 
introduced and conceptualized in 1985 by Albert and Whetten. According to this definition, organizational identity is considered as a set of comments of the members of an organization about the perceived properties of their organization. These properties include distinguishing characteristics and traits and the stability and continuity of central and axial properties of the organization (Puusa, 2006). The definition of Albert and Whetten (1985) of organizational identity in the recent two decades has been accepted by many authors as a dominant and common definition of this concept and many research works that have been conducted in this regard also depended on this definition (Dhalla, 2007).

Cheney (1982) determined three fundamental and key concepts regarding organizational identity: the first concept pointed to a strong internal and emotional attachment which was called feelings of solidarity (membership). The second concept was loyalty which meant attitudinal and behavioral support and protection for the organization and its values and goals. The third concept was the awareness of the existence of common properties with other members of the organization or perceptions of shared characteristics (similarity); i.e. the people in the organization feel that they have common goals and interests with other members of the organization (Cheney, 1982).

Also, in other research, surveying papers and researches regarding identity and organizational relationships, Cheney provided more details about the concept of organizational identity and its different aspects and in executing this structure he pointed to three elements of membership, loyalty to the organization and similarity as fundamental elements and components of organizational identity (Cheney, 1983a,b).
According to Hatch \& Schultz organizational identity is a concept based on which the members of an organization consider themselves a part of the whole organization and not a certain group or their own expertise or position and they like to be identified by those properties. Issues such as the level of loyalty to the organization and the managers of the organization, feeling the pride of being a member of the organization, tendency to remain in the organization and defending the values of the organization inside and outside the organization are among the factors of identifying this identity (Hatch \& Schultz, 2004).

Albert and Whetten (1985) argue that organizational identity is (a) what is taken by employees to be the central attributes of the organization; (b) what makes the organization distinctive and therefore unique from other organizations in the eyes of the employees; and (c) what is perceived by employees to be enduring or continuing, regardless of objective changes in the organizational environments (He \& Baruch, 2009).

Organizational identity causes the members of an organization to be more committed and to be volunteer to engage in organizational activities, try to have perfect performance and play extra-roles in line with the goals of their organization (Gholipour \& Amiri, 2009).

Organizational identity is important since it affects the performance and measures, explanation, interpretation and decision making of the members and managers of an organization. From a more concrete viewpoint, organizational identity influences management and members within an organization in several ways; from organizational leaders' actions and decision making regarding change initiatives, in the 
members' interpretation of organizational events and actions. Moreover, organizational identity affects members' comparison processes and evaluation of strategies and actions as well. Also, the results obtained from several researches have shown that organizational identity has a deep impact on the process of changing of the organization and due to its positive and significant consequences it is considered as a competitive advantage for its (Lin, 2004).

\section{RESEARCH BACKGROUND}

A behavior based on the properties of transformational leadership is one of the basic factors affecting some important attitudinal and organizational variables, including organizational identity, among the staff of the organization. Direct and indirect positive effects of transformational leadership style on the organizational identity has been studied in several researches and the relationship between each of its components with each of the three dimensions of the organizational variables often has been approved.

In a research on 553 personnel of Ilam Province Petrochemical Complex showed that there was a positive and meaningful relationship between transformational leadership style and organizational identity of the members. In addition, the effect of transformational leadership style and its elements, on the organizational identity of staff was a significant effect (Rezaee et al., 2014).

In a study of 1100 high school teachers in district 5 of west of Tehran, Salajeghe and Ahmadzadeh showed that transformational leadership had a positive and meaningful effect on the organizational identity of teachers and organizational identity improved organizational commitment and organizational citizenship behavior. Also, the indirect effect of transformational leadership of the managers on job attitudes among the teachers, including organizational commitment and organizational citizenship behavior, was stronger than its direct effect (Salajeghe \& Ahmadzadeh, 2014).

In a research on 1370 staff members of entrepreneurship organizations in 24 different branches in Khuzestan Province Iran, Albonaiemi and Mahmoodi showed that transformational leadership style did not have a significant effect on the entrepreneurship behavior of the personnel of these organizations. However, the transformational leadership style had a meaningful effect on the organizational identity of the staff members. Also, the effect of organizational identity on the behavior of the personnel was reported to be positive and meaningful (Albonaiemi \& Mahmoodi, 2016).

In a research on 300 staff members on different industries in a few provinces of China, $\mathrm{Hu}$ et al., showed that transformational leadership style had a positive and meaningful effect on all aspects of the organizational identity of the staff members (Hu et al., 2015).

\subsection{Conceptual Model of the Research}

Conceptual Model of this research is shown in Figure 1. In this model dimension of independent variable (transformational leadership) and dependent variable (organizational identity) are shown.

\subsection{Research Question and Hypothesis}

The purpose of the study was to 
investigate the relationship between transformational leadership style and organizational identity of faculty members in the state universities of West Azerbaijan Province, Iran. In order to achieve the purpose of the study, the following research question was postulated:

Is there a significant relationship between transformational leadership style and organizational identity of faculty members in the state universities of West Azerbaijan Province, Iran?

\section{The main hypothesis of the research:}

There is a significant relationship between transformational leadership style and organizational identity of faculty members in the state universities of West Azerbaijan Province - Iran.

The Sub-hypotheses of the research:

There is a significant relationship between the idealized influence and organizational identity of faculty members.

There is a significant relationship between the inspirational motivation and organizational identity of faculty members.

There is a significant relationship between the intellectual stimulation and organizational identity of faculty members.

There is a significant relationship between the individual considerations and organizational identity of faculty members.

In this research it has also been tried to answer the following question:

Is there a meaningful difference between the visions and opinions of faculty members in the state universities of West Azerbaijan Province - Iran about the relationship and influence of transformational leadership style on dependent variables in this research?

\section{RESEARCH METHODOLOGY}

This study examined the relationship between transformational leadership style and organizational identity of faculty members in the state universities of West Azerbaijan Province, Iran. The design of the study was descriptive and correlational. The statistical population consisted of the research was consisted of (formal and contractual) currently working in the state universities of West Azerbaijani Province Iran whose number was 765 when the research was being conducted. Among them, 178 were from Payam-e Nour University, 94 from Urmia industrial university and 493 from National University and its subsidiaries



Figure 1. Conceptual Model of the Research 
in different cities of the province. The Statistical sample size of the research was determined to be 256 persons, according to Morgan table who were selected by stratified sampling method from the statistical population. Since 300 questionnaires were distributed, data analysis was conducted based on 283 persons, using SPSS and LISREL software.

\subsection{Procedures and tools of data collection for research}

Questionnaires were used for collecting a part of the basic information needed for this research. Standard questionnaires were prepared and used according to each studied variable (variables of transformational leadership and organizational identity).The reliability of multifactor leadership questionnaire (MLQ) and organizational identity questionnaire (OIQ) was calculated to be 0.96 and 0.85 , respectively.

\subsubsection{Multifactor Questionnaire (MLQ) \\ leadership}

Multifactor leadership questionnaire (MLQ) was first used in the works of Bass in 1985 and, in addition to modification and completion, since then it has been tested in more than 1000 organizations in different

Table 1. Cronbach's alpha coefficients for (MLQ)

\begin{tabular}{lr}
\hline Element & $\begin{array}{c}\text { Cronbach's } \\
\text { alpha coefficient }\end{array}$ \\
\hline Idealized influence & 0.74 \\
Idealized behavior & 0.71 \\
Inspirational motivation & 0.82 \\
Intellectual stimulation & 0.87 \\
Individual considerations & 0.76 \\
Contingent award & 0.72 \\
Active management-by-exception & 0.85 \\
Passive management-by-exception & 0.76 \\
Laissez-fair leadership & 0.73 \\
Total questionnaire & $\mathbf{0 . 9 6}$ \\
\hline
\end{tabular}

countries (Moghali, 2003). These questionnaires, by combining three styles of transformational leadership, transactional leadership and laissez-faire leadership, puts the responders in the position where they mark what is closer to reality. In this research, for collecting data regarding transformational leadership, standard MLQ was used for which acceptable validities and reliabilities have been reported in many researches in recent years. MLQ questionnaire included 36 questions among which 20 items (4 items per subcomponent) measured transformational leadership dimensions and 12 items (4 items per subcomponent) measured transactional leadership dimensions. In order to measure Laissez fair leadership there was 4 items. This questionnaire was prepared according to Likert's 5 point scale.In Table 1, Cronbach's alpha coefficients are shown for various components of multifactor leadership questionnaire.

\subsubsection{Organizational Identity Questionnaire (OIQ)}

Standard organizational identity questionnaire (OIQ) was first introduced and validated by Cheney in 1982 and has been widely used in national and foreign research works for investigating the three components of organizational identity. Basically, this questionnaire has 25 questions, but in the factor analysis conducted by Miller et al., in

Table 2. Cronbach's alpha coefficients for (OIQ)

\begin{tabular}{lr}
\hline Element & $\begin{array}{c}\text { Cronbach s ' alpha } \\
\text { coefficient }\end{array}$ \\
\hline Loyalty & 0.83 \\
Similarity & 0.76 \\
Membership & 0.74 \\
Total questionnaire & $\mathbf{0 . 8 5}$ \\
\hline
\end{tabular}


2000 , the number of the items of this questionnaire was reduced to 12 (Mousavi and Farsani, 2012). Thus, the scale consisted of 12 items with responses anchored in 7 points (ranging from completely agree to completely disagree).In Table 2, Cronbach's alpha coefficients are shown for components of organizational identity questionnaire.

\section{RESEARCH FINDINGS}

The results obtained from this research were analyzed in two different sections of descriptive and inferential statistics.

\subsection{Descriptive findings}

In this section, descriptive indices of the research sample including frequency and frequency percentage were provided separately for each university for the variables of gender and academic rank of professors. Also, the indices of the mean and standard deviation as well as the results of investigating the normality of the result distributions were presented.

According to table 3, the number of women in Urmia University, Industrial University and Payam-e Nour University were 32, 3 and 17 and for men they were 116, 43 and 72, respectively. In all among 283 studied samples $52(26.5 \%)$ were women and $231(81.5 \%)$ were men.

According to table 4, the number of professors, associate professors, assistant professors and educators in each state university of West Azerbaijan Province indicated. Totally, 283 samples were investigated among which $36(12.8 \%)$ were professors, $86(30.3 \%)$ were associate professors, $152(53.6 \%)$ were assistant professors and $9(2.3 \%)$ were educators.

According to table 5, the values obtained for the indices of mean, standard deviation, minimum and maximum scores of the tested Table 3. Frequency of gender variable for each university

\begin{tabular}{|c|c|c|c|c|c|c|c|c|}
\hline \multirow[t]{2}{*}{ Gender } & \multicolumn{2}{|c|}{ Urmia university } & \multicolumn{2}{|c|}{ Industrial university } & \multicolumn{2}{|c|}{$\begin{array}{c}\text { Payam-e Nour } \\
\text { university }\end{array}$} & \multicolumn{2}{|c|}{ Total Sample } \\
\hline & f & $\mathrm{P}$ & $\mathrm{f}$ & $\mathrm{P}$ & $\mathrm{f}$ & $\mathrm{P}$ & $\mathrm{f}$ & $\mathrm{P}$ \\
\hline Women & 32 & 21.8 & 3 & 7.3 & 17 & 18.7 & 52 & 18.5 \\
\hline Men & 116 & 78.2 & 43 & 92.7 & 82 & 81.3 & 231 & 81.5 \\
\hline Total & 148 & 100 & 46 & 100 & 89 & 100 & 283 & 100 \\
\hline
\end{tabular}

Table 4. Frequency of academic rank variable separately for each university

\begin{tabular}{lcccccccc}
\hline \multirow{2}{*}{ Academic rank } & \multicolumn{2}{c}{ Urmia university } & \multicolumn{2}{c}{ Industrial University } & \multicolumn{2}{c}{ Payam-e Nour University } & \multicolumn{2}{c}{ Total Sample } \\
\cline { 2 - 9 } & $\mathrm{F}$ & $\mathrm{P}$ & $\mathrm{F}$ & $\mathrm{P}$ & $\mathrm{F}$ & $\mathrm{P}$ & $\mathrm{F}$ & $\mathrm{P}$ \\
\hline Professor & 26 & 17.57 & 9 & 19.93 & 1 & 1.12 & 36 & 12.8 \\
Associate Professor & 49 & 33.11 & 16 & 34.38 & 21 & 23.6 & 86 & 30.3 \\
Assistant Professor & 73 & 49.32 & 21 & 45.69 & 58 & 65.17 & 152 & 53.8 \\
Educator & 0 & 0 & 0 & 0 & 9 & 10.11 & 9 & 2.3 \\
Total & $\mathbf{1 4 8}$ & $\mathbf{1 0 0}$ & $\mathbf{4 6}$ & $\mathbf{1 0 0}$ & $\mathbf{8 9}$ & $\mathbf{1 0 0}$ & $\mathbf{2 8 3}$ & $\mathbf{1 0 0}$ \\
\hline
\end{tabular}

Table 5. Mean, standard deviation and the results of normality test for data distribution

\begin{tabular}{lcccccc}
\hline \multicolumn{1}{c}{ Variable } & Minimum & Maximum & Mean & Standard deviation & Skewness & Kurtosis \\
\hline Transformational leadership style & 1.75 & 4.56 & 3.46 & 0.51 & -0.69 & 0.51 \\
Organizational identity & 1.25 & 4.83 & 3.96 & 0.57 & -1.36 & 2.90 \\
\hline
\end{tabular}


research variables show the proper distribution of the data. To investigate the normality of data distribution, Kline (2011) believes that in samples consisting of more than 100 people the results of KolmogorovSmirnov test is generally meaningful; therefore, this test was not suitable to be used in studying the normality of the variables in our research whose sample population was 283 people. He suggested that when the sample volume is higher than 100 people, skewness and kurtosis were suitable for investigating the normality. Kline (2011) stated that if the absolute values of skewness and kurtosis of the variables were less than 1 and 10 , respectively, it can be concluded that the variables had normal distribution. Considering Klein's statement as sohwn in tables 6 and 7, skewness indices of all variables were lower than 2 and their kurtosis indices were lower than 10 which shows the normality of data distribution.

\subsection{Inferential statistics findings}

In this section, after being sure that the data distribution was normal, first the credit of the structure of the questionnaires of transformational leadership style and organizational identity was ere determined using confirmatory factor analysis method. Then, using Pearson correlation coefficient tests, the presence of a meaningful relationship between the independent variable (transformational leadership) and dependent variable (organizational identity) was investigated. In the following step, the relationship between the elements of transformational relationship and organizational identity among the faculty members was evaluated. Direct and indirect effects of transformational leadership style on the organizational identity among the faculty members was also analyzed using structural equation modeling method and the results obtained from each step was summarized in the corresponding tables.

\subsection{Confirmatory factor analysis of research questionnaires}

In order to determine the structures of transformational leadership style and organizational identity questionnaires, confirmatory factor analysis method was used. Characteristics of goodness of fit for final analysis of these questionnaires are summarized in tables 6 and 7.

According to the results presented in table 6 , the calculated value of $\chi^{2} / d f$ was 2.17 . The values of $\chi^{2} / d f$ below 3 indicate suitable fitness of the model.

Also, the root mean square error of approximation (RMSEA) should be below 0.08 which was calculated to be 0.06 in the proposed model.

The value of root mean residues (RMR) should also be below 0.1 which was 0.04 in the proposed model.

The values of the statistical indices of AGFI, NFI, CFI and GFI should be above 0.9 and the values calculated for the proposed model were all above the determined value. Therefore, the data obtained from this research had a proper fitness scale with factorial structure and this

Table 6. Fitness indices for transformational leadership style questionnaires

\begin{tabular}{lccccccc}
\hline Fitness indices & RMR & $\chi^{2} / \mathrm{df}$ & RMSEA & GFI & CFI & NFI & AGFI \\
\hline Acceptance domain & $<0.1$ & $<3$ & $<0.08$ & $>0.9$ & $>0.9$ & $>0.9$ & $>0.9$ \\
Calculated value & 0.04 & 2.17 & 0.06 & 0.99 & 0.99 & 0.99 & 0.99 \\
\hline
\end{tabular}


Table 7. Fitness indices for organizational identity questionnaires

\begin{tabular}{lccccccc}
\hline Fitness indices & RMR & $\chi^{2} / \mathrm{df}$ & RMSEA & GFI & CFI & NFI & AGFI \\
\hline Acceptance domain & $<0.1$ & $<3$ & $<0.08$ & $>0.9$ & $>0.9$ & $>0.9$ & $>0.9$ \\
Calculated value & 0.02 & 2.08 & 0.07 & 0.99 & 0.95 & 0.95 & 0.91 \\
\hline
\end{tabular}

Table 8: the relationship between transformational leadership style and identity

\begin{tabular}{ccccc}
\hline Independent variable & Dependent variable & $\begin{array}{c}\text { Type of } \\
\text { hypothesis }\end{array}$ & $\begin{array}{c}\text { Pearson's correlation } \\
\text { coefficient }\end{array}$ & $\begin{array}{c}\text { Confirmation/rejection of } \\
\text { the hypothesis }\end{array}$ \\
\hline $\begin{array}{c}\text { Transformational } \\
\text { leadership style }\end{array}$ & $\begin{array}{c}\text { Organizational } \\
\text { identity }\end{array}$ & Main & $0.26^{* * *}$ & Confirmed \\
${ }^{* * *} \mathrm{p}<0.01$ & & & &
\end{tabular}

indicated the compliance of the questions on the questionnaire and different aspects of transformational leadership style.

According to the results presented in table 7 , the calculated value of $\chi^{2} / d f$ was 2.08 . The values of $\chi^{2} / d f$ below 3 indicate suitable fitness of the model.

Also, the root mean square error of approximation (RMSEA) should be below 0.08 which was calculated to be 0.07 in the proposed model.

The value of root mean residues (RMR) should also be below 0.1 which was 0.02 in the proposed model.

The values of the statistical indices of AGFI, NFI, CFI and GFI should be above 0.9 and the values calculated for the proposed model were all above the determined value. Therefore, the data obtained from this research had had a proper fitness with factorial structure and this indicated the compliance of the questions on the questionnaire and different aspects of organizational identity.

\subsection{Evaluation of the main hypothesis of the research}

There is a significant relationship between transformational leadership style and organizational identity among the faculty members in the state universities of West
Azerbaijan Province - Iran.

In order to investigate the relationship between transformational leadership style and organizational identity, Pearson's correlation coefficient was used. Table 13 summarizes the results of this test.

According to Pearson's correlation coefficient in table 8 , it can be concluded that there was a significant and positive relationship between the transformational leadership style and organizational identity at the statistical level of 0.01 .

Therefore, the main hypothesis of the research was confirmed and it can be said that there was a meaningful relationship between transformational leadership style and organizational identity among the faculty member of state universities in West Azerbaijan Province - Iran.

\subsection{Evaluation of the sub-hypothesis of the research}

There is a significant relationship between the idealized influence and organizational identity of faculty members.

There is a significant relationship between the idealized behavior and organizational identity of faculty members.

There is a significant relationship between the inspirational motivation and organizational identity of faculty members. 
There is a significant relationship between the intellectual stimulation and organizational identity of faculty members.

There is a significant relationship between the individual considerations and organizational identity of faculty members.

In order to investigate the relationship between different dimensions of transformational leadership style and organizational identity, Pearson's correlation coefficient was used. Table 13 summarizes the results of this test.

According to table 9, regarding the secondary goals of the research it can be concluded that there was a significant and positive relationship between the Idealized behavior, intellectual stimulation and inspirational motivation dimensions of transformational leadership style and organizational identity at the 0.01 level. Therefore, it can be said that there was a meaningful relationship between the Idealized behavior, intellectual stimulation and inspirational motivation dimensions of transformational leadership style and organizational identity among faculty members of state universities in West Azerbaijan Province - Iran.

There was no significant relationship between Idealized influence and individual considerations transformational leadership style and organizational identity. Therefore, it can be said that there was no meaningful relationship between the Idealized influence and individual considerations dimensions of transformational leadership style and organizational identity among faculty members of state universities in West Azerbaijan Province - Iran.

There was a significant relationship between the active management-byexception and contingent award dimensions of transactional leadership and organizational identity at the 0.01 level. Also, there was a significant relationship between the Passive management-byexception dimension of transactional leadership and organizational identity at 0.05 levels.

Therefore, it can be said that there was a meaningful relationship between the active management-by-exception, the Passive management-by-exception and contingent award dimensions of transactional leadership and organizational identity among faculty members of state universities in West Azerbaijan Province - Iran.

The relationship between laissez-faire leadership style and organizational identity was not significant. Therefore, it can be said that there was no meaningful relationship

Table 9. Correlation matrix of different dimensions of transformational leadership and organizational identity

\begin{tabular}{cllccccccccc}
\hline No. & \multicolumn{1}{c}{ Variables } & 1 & 2 & 3 & 4 & 5 & 6 & 7 & 8 & 9 & 10 \\
\hline 1 & Idealized influence & 1 & & & & & & & & & \\
2 & Idealized behavior & $0.53^{* *}$ & 1 & & & & & & & \\
3 & Inspirational motivation & $0.18^{* *}$ & $0.38^{* *}$ & 1 & & & & & & \\
4 & Intellectual stimulation & $0.22^{* *}$ & $0.33^{* *}$ & $0.68^{* *}$ & 1 & & & & & \\
5 & Individual consideration & $-0.09^{* *}$ & $0.17^{* *}$ & $0.44^{* *}$ & $0.64^{* * *}$ & 1 & & & & \\
6 & Contingent award & $0.20^{* *}$ & $0.22^{* *}$ & $0.39^{* *}$ & $0.66^{* *}$ & $0.68^{* *}$ & 1 & & & \\
7 & Active management-by-exception & $0.23^{* *}$ & $0.36^{* *}$ & $0.51^{* *}$ & $0.49^{* *}$ & $0.41^{* *}$ & $0.40^{* *}$ & 1 & & & \\
8 & Passive management-by-exception & $0.47^{* *}$ & $0.30^{* *}$ & $0.19^{* *}$ & $0.03^{* *}$ & $-0.28^{* *}$ & $-0.05^{* *}$ & 0.18 & 1 & & \\
9 & Laissez -faire leadership & $0.40^{* *}$ & $0.20^{* *}$ & -0.10 & $-0.20^{* *}$ & $-0.45^{* *}$ & $-0.18^{* *}$ & 0.05 & $0.72^{* *}$ & 1 \\
10 & Organizational identity & 0.10 & $0.22^{* *}$ & $0.16^{* *}$ & $0.24^{* *}$ & 0.09 & $0.24^{* *}$ & $0.15^{* *}$ & $0.13^{*}$ & 0.09 & 1 \\
\hline${ }^{*}<<0.05, * * \mathrm{p}<0.01$ & & & & & & & & & & &
\end{tabular}


between laissez-faire leadership style and organizational identity among faculty members in the state universities in West Azerbaijan Province - Iran.

\subsection{Evaluation of the effect of} transformational leadership style on organizational identity of faculty members

Stage 1: Designing statistical hypothesis

Transformational leadership style has a direct effect on the organizational identity of faculty members of state universities in West Azerbaijan Province - Iran.

Stage 2: Hypothesis test

Investigation of direct, indirect, total and variance effect of transformational leadership style on organizational identity was analyzed using structural equation modeling and the obtained results are shown in tables 10 and 11 .

According to table 10, since at error level below 0.01 , t-statistics has the positive value of 2.66, it can be concluded that this relationship was meaningful. On the other hand, the value of path coefficient $(\beta)$ as calculated to be 0.16 which is a positive value, it can be said with $99 \%$ confidence that transformational leadership style had a significant and positive effect on the organizational identity among faculty members and the statistical hypothesis designed based on the direct effect of transformational leadership style on organizational identity was confirmed and it can be said that transformational leadership style had a meaningful and direct effect on the organizational identity among faculty members in state universities in West Azerbaijan Province.

According to table 11, the direct effect of transformational leadership on organizational leadership at the 0.01 error level was stronger than its indirect effect; transformational leadership predicted $13 \%$ of organizational identity variation.

\section{Response to the research question:}

Is there a meaningful difference among the ideas and visions of faculty members of the universities in West Azerbaijan Province - Iran regards the relationship and the effectiveness of transformational leadership style on the dependent variable of the research?

Table 10. The results obtained from investigating the second hypothesis of the research

\begin{tabular}{clcccc}
\hline No. & \multicolumn{1}{c}{ Hypothesis } & $\begin{array}{c}\text { Path coefficient } \\
(\beta)\end{array}$ & T- statistics & $\begin{array}{c}\text { Significance } \\
\text { level }\end{array}$ & Status \\
\hline $1 \quad \begin{array}{l}\text { Transformational leadership has a direct } \\
\text { effect on organizational identity of } \\
\text { faculty members. }\end{array}$ & 0.16 & 2.66 & 0.008 & Confirmed \\
\hline
\end{tabular}

Table11. Direct, indirect, total and explained variance effects of the variables

\begin{tabular}{ccccc}
\hline Path & Direct effect & Indirect effect & Total effect & $\begin{array}{c}\text { Explained } \\
\text { variance }\end{array}$ \\
\hline $\begin{array}{c}\text { From transformational leadership to } \\
\text { organizational identity }\end{array}$ & $0.16^{* *}$ & $0.07 * *$ & $0.23^{* * *}$ & 0.13 \\
\hline${ }^{*} \mathrm{p}<0.05,{ }^{* *} \mathrm{p}<0.01, * * * \mathrm{p}<0.001$ & & & &
\end{tabular}


Table 12. Mean of research variables for each university

\begin{tabular}{lccc}
\hline Variable & Urmia University & Industrial University & $\begin{array}{c}\text { Payam-e Nour } \\
\text { University }\end{array}$ \\
\hline Transformational leadership style & 3.61 & 3.55 & 3.48 \\
Organizational identity & 3.94 & 3.93 & 3.80 \\
\hline
\end{tabular}

\section{Stage one: designing statistical hypothesis}

$\mathbf{H}_{\mathbf{0}}$ hypothesis: There is no meaningful difference among the ideas and visions of faculty members of state universities in West Azerbaijan Province - Iran regards the type of relationship and effectiveness of transformational leadership style on the dependent variable of the research.

$\mathrm{H}_{0}: \mu_{1}=\mu_{2}$

$\mathrm{H}_{1}$ hypothesis: There is a meaningful difference between the ideas and visions of faculty members in the state universities of West Azerbaijan Province - Iran regards the type of relationship and effectiveness of transformational leadership style on the dependent variable of the research.

$\mathrm{H}_{0}: \mu_{1}=\mu_{2}$

\section{Stage two: Hypothesis test}

In order to investigate the differences in the visions and ideas of faculty members in Urmia University, Industrial University and Payam-e Nour University regards, the relationship and effectiveness of transformational leadership style on their organizational identity, first the mean of research variables for each university indicated in table 12 , then multi-way ANOVA was used for their analysis. $P<0.05$ level was considered to reject the null hypothesis. The Partial Eta squared was used to investigate the extent of the effect. The value of partial Eta squared in the range of
(0.01) and less, at (0.04) and (0.10) and more than, represents the low effect, an average, and high effect respectfully. Before presenting multi-way ANOVA tests, the Table 13: investigation of the assumption of homogeneity of covariance matrix

\begin{tabular}{lll}
\hline M-box statistic & F & Significance level \\
\hline 17.47 & 0.96 & 0.57 \\
\hline
\end{tabular}

results obtained from M-box test was reported in table 13 to investigate the equality of covariance matrix of the dependent variables among the groups.

According to table 13, $F$ statistics of Mbox test (0.96) was not meaningful. Therefore, it can be concluded that the covariance matrices of the dependent variables were equal for the groups.

According to table 14, Wilks lambda statistics for the investigation of group differences in regards to research variables was 0.03 . The $F$ item of this test $(0.60)$ was not meaningful either. Therefore, can be said there is no meaningful difference between the visions and ideas of faculty members at Urmia University, Industrial University and Payam-e Nour University. To further investigate the differences and the results obtained from one - way ANOVA analysis, are reported in table 15. Also, according to table 14 the partial eta squared showed that group membership explained only $1 \%$ of the variation in the dependent variable. Therefore, in this research group membership had a small effect on research variables. In other words the difference among the groups in the society was very 
Table 14: the results obtained from multi-way ANOVA analysis regarding the variables of the research in the groups

\begin{tabular}{lcccccc}
\hline Test & Value & F & Df1 & Df2 & P & Partial Eta Squared \\
\hline Pilaei effect & 0.03 & 0.60 & 14 & 550 & 0.86 & 0.01 \\
Wilks lambda & 0.03 & 0.60 & 14 & 548 & 0.86 & 0.01 \\
Hotling effect & 0.03 & 0.60 & 14 & 546 & 0.86 & 0.01 \\
Biggest root & 0.02 & 0.96 & 7 & 275 & 0.45 & 0.01 \\
\hline
\end{tabular}

Table 15. The results obtained from one-way ANOVA analysis of the differences among different groups in research variables

\begin{tabular}{lcccccc}
\multicolumn{1}{c}{ Variable } & SS group & SS error & MS group & MS error & F & P \\
\hline Transformational leadership style & 0.86 & 74.91 & 0.43 & 0.26 & 1.62 & 0.19 \\
Organizational identity & 1.15 & 120.59 & 0.57 & 0.43 & 1.34 & 0.26 \\
\hline
\end{tabular}

small (0.60).

According to table $15, F$ statistics were 1.62 and 1.34 for transformational leadership style and organizational identity, respectively. This shows that there was no meaningful difference among the ideas and visions of faculty members in Urmia University, Industrial University and Payame Nour University in the research variables.

\section{RESULTS AND DISCUSSION}

The results obtained from this research showed that there was a positive and direct relationship between transformational leadership style and organizational identity of faculty members in the state universities of West Azerbaijan Province - Iran $(r=0.26$, $p<0.01)$. Accurate investigation of the results also showed that, among different components of transformational leadership style, intellectual stimulation had the strongest effect on organizational identity of faculty members compared to its other dimensions. It can be concluded that, by considering the importance of such features of a leadership style and enjoying them, the managers of the state of West Azerbaijan Province could have a significant and positive impact on the visions and behaviors of faculty members and therefore, their organizational identity would be stronger. Earning more organizational identity by these valuable scientific assets, strengthens their sense of emotional attachment and dependency to the organization as well as their loyalty and commitment to the values and goals of the organization, improves their achievement, creates stronger motivations for more effort and increases the quality of their educational services in different scientific and cultural activities. The presence of a strong and integrated organizational identity in the educational organizations is an important competitive advantage by itself and is an important factor in the effectiveness of the educational organizations in achieving transcendent values and goals and help them efficiently play their important and productive roles as in the way of economic, social and cultural progress of this region of the country. In addition, according to the findings of this research, it can be predicted that the application of transformational leadership patterns in the state universities of this province can result in fundamental transformations in the structure, process and targeting of the educational organizations 
and increase the ability of these dynamic and effective social systems in interacting with their turbulent and changing environment. It is obvious that, the achievement of such a goal of gaining a better understanding of the significant and obvious principles and properties of transformational leadership style and also by identifying environmental barriers and restrictions of the environment would allow the application of transformational leadership style among the state universities of West Azerbaijan Province - Iran. The relationships between the organizational identity of faculty members of the universities, transactional and laissez-faire leadership styles were also reported as positive and meaningful in this research. The importance of these leadership styles and the positive effects of their properties on the organizational identities of faculty members should also be considered by the managers and leaders of these universities and in appropriate situations; they should be used as supplements for the properties of transformational leadership. According to the analytical results of the data obtained from this research (results of ANOVA and investigation of the mean values among the groups and other statistical tests), it was also determined that there was no meaningful difference among the visions and ideas of faculty members in the state universities of the province regarding the application of transformational leadership style in the mentioned educational organizations and its positive effects on faculty members organizational identities.

\section{References}

Albert, S., \& Whetten, D.A. (1985). Organizational identity. In Larry L.
Cummings., and Barry M. Staw (Eds.), Research in organizational behavior. An annual series of analytical essays and critical reviews, Greenwich: JAI Press, 263-295.

Albonaiemi, E., \& Mahmoodi, K. (2016). Investigating the Effects of Leadership Styles and Organizational Identity on Entrepreneurial Behavior of the Employees of Iranian Social Security Organization in Khuzestan Province, Iran. International Journal of Humanities and Cultural Studies, Special Issue, 1450-1468.

Burns, J.M. (1978). Leadership. New York: Harper \& Row.

Bass, B.M. (1985). Leadership and performance beyond expectations. New York: The Free Press.

Bass, B.M., Avolio, B.J., Jung, D.I., \& Berson, Y. (2003). Predicting unit performance by assessing transformational and transactional leadership. Journal of Applied Psychology, 88(2), 207-218.

Barling, J., Slater, F., \& Kelloway, E.K. (2000). Transformational leadership and emotional intelligence: An exploratory study. Leadership \& Organization Development, 21(3), 157-161.

Basham, L.M. (2010). Transformational and Transactional Leaders in Higher Education. International Review of Business Research Papers, 6(6), $141-152$.

Beugré, C.D., Acar, W., \& Braun, W. (2006).Transformational leadership in organizations: an environment induced model. International Journal of Manpower, 27(1), 52-62.

Cheney, G. (1982). Organizational identification as process and product: A field study. Unpublished master's thesis, Purdue University.

Cheney, G. (1983a). On the various and changing meanings of organizational membership: A field study of organizational 


\title{
ИСПИТИВАЊЕ ОДНОСА ИЗМЕЪУ ТРАНСФОРМАЦИОНОГ СТИЛА ЛИДЕРСТВА И ОРГАНИЗАЦИОНОГ ИДЕНТИТЕТА ЧЛАНОВА ФАКУЛТЕТА ДРЖАВНИХ УНИВЕРЗИТЕТА ПРОВИНЦИЈЕ ЗАПАДНИ АЗЕРБЕЈЏАН, ИРАН
}

\author{
Ali Pourmahmoud Hesar, Mir Mohammad Seyed Abbaszadeh, Alireza Ghalei, \\ Hassan Ghalavandi
}

\section{Извод}

Циљ овог истраживања био је истраживање односа између трансформационог стила лидерства и организационог идентитета чланова факултета на државним универзитетима провинције Западни Азербајџан, Иран. Ово истраживање је дескриптивна и корелациона студија. Статистичка популација истраживања обухватила је све чланове факултета на овим универзитетима чији је број био 765 у вриеме истраживања. Користећи Морганову табелу и стратификовану методу случајног узорковања, изабрано је 256 особа као статистички узорак истраживања. Дистрибуирано је 300 упитника, од којих је 283 враћено, а финална анализа података је спроведена за 283 испитаника користећи софтвере „SPSS“ и „LISREL“. Стандардни вишефакторски лидерски упитник (ВЛУ) и Ченејев упитник о организационом идентитету (Cheney, 1982) коришћени су за прикупљање података о трансформационом лидерству и организационом идентитету, респективно. Поузданост упитника је израчуната као 0.96 и 0.85, респективно, користећи Кронбах алфа коефицијент. Хипотезе и претпостављене везе између варијабли у предложеном теоријском моделу истраживане су коришћењем регресионе анализе и модела структурне једначине. Резултати добијени овим истраживањем показали су да постоји позитивна и значајна веза између стила трансформационог лидерства и његових варијабли и организационог идентитета чланова факултета на државним универзитетима провинције Западни Азербаијан, Иран ( $<<0.01, \mathrm{r}=$ 0.26). Поред тога, статистички резултати добијени овим истраживањем указали су на позитиван и директан ефекат трансформационог лидерског стила на организациони идентитет чланова факултета. Резултати су такође показали да је међу различитим компонентама трансформационог лидерског стила интелектуална стимулација имала најјачи ефекат на организациони идентитет чланова факултета.

Кључне речи: лидерство, трансформационо лидерство, идентитет, факултет

identification. Communication Monographs, 10(4), 245-260.

50, 342-362.

Cheney, G. (1983b). The rhetoric of identification and the study of organizational communication. Quarterly Journal of Speech, 69, 143-158.

Dhalla, R. (2007). The Construction of Organizational Identity: Key Contributing External and Intra-Organizational Factors. Journal of Corporate Reputation Review,
Hu, D., Zhang, B., \& Wang, M. (2015). A Study on the Relationship among Transformational Leadership, Organizational Identification and Voice Behavior. Journal of Service Science and Management, 2015, 8, 142-148.

Ergenelia, A., Goharb, R., \& Temirbekovac, Z. (2007). Transformational leadership: Its Relationship to Culture value 
Dimensions. International Journal of of Guilford Publications, Inc. 72 Spring Intercultural Relations, 31, 703-724.

Street, New York, NY 10012.

Fasola, O.S., Adeyemi, M.S., \& Olowe, F.T. (2013).Exploring the Relationship between Transformational, Transactional Leadership Style and Organizational Commitment among Nigerian Banks Employees. International Journal of Academic Research in Economics and Management Sciences, 2(6), 96-107.

Gholipour, A., \& Amiri, B. (2009). Impact information technology on organizational behavior: examination of identity challenges in virtual teams and its impact on behavior of team members. Information Technology Management Magazine, 1 (2), 103-118, (In Persian).

Hatch, M., \& Schultz, M. (2004). Introduction. In M. Hatch and M. Schultz (Eds.), Organizational Identity: A reader (pp. 1- 6). Oxford: Oxford University Press.

Humphreys J.H., \& Einstein W.O. (2003). Nothing new under the sun: transformational leadership from a historical perspective, Management Decision, 41(1), 85-95.

He, H., \& Baruch, Y. (2009). Transforming organizational identity under institutional change. Journal of Organizational Change Management, 22 (6), 575-599.

Jung, D.D., \& Sosik, J.J. (2002). Transformational Leadership in Work Groups: The Role of Empowerment, Cohesiveness, and Collective-Efficacy on Perceived Group Performance. Small Group Research. 33, 313-336.

Krishnan, V.R. (2005). Transformational leadership and outcomes: Role of relationship duration. Leadership \& Organization Journal, 26 (5/6), 442-457.

Kline, R.B. (2011). Principles and practice of structural equation modeling. Second Edition, the Guilford Press, Division

Lin, Y.Y. (2004). Organizational identity and its implication on organization development, Paper presented at the Academy of Human Resource Development International Conference (AHRD) (Austin, TX, Mar 3-7, 2004), 803-810.

Miller, V. D., Allen, M., Casey, M. K., \& Johnson, J. R . (2000). Reconsidering the organizational identification questionnaire. Management Communication Quarterly, 13 (4), 626-658.

Mousavi, S., \& Farsani, K.Z. (2012). The relationship between religious attitudes with organizational identity among employees of Isfahan University of Medical Sciences, The third National Consultation Conference, Islamic Azad University, Khomeini Shahr branch, 1-9, (in Persian).

Muceke Ng'ethe, J., Namusonge, G.S., \& Iravo, M.A. (2012). Influence of Leadership Style on Academic Staff Retention in Public Universities in Kenya. International Journal of Business and Social Science, 3(21), 297302.

Mohd Nasir H., Nordin, R., Abu Seman S. A., \& Rahmat A. (2014). The Relationship of Leadership Styles and organizational performance among IPTA Academic Leaders in Klang Valley Area. Malaysia Business \& Entrepreneurship Journal, 3(2), 45-65.

Moghali, A. (2003). Designing a model of transformational leadership in the administrative organizations of Iran. Journal of Knowledge of Management, 62, 100-77, (In Persian).

Odumeru, J.A., \& Ifeanyi, G.O. (2013). Transformational vs. Transactional Leadership Theories: Evidence in Literatures. International Review of Management and Business Research, 2(2), 355-361. 
Puusa, A. (2006). Conducting Research on Organizational Identity. EJBO Electronic Journal of Business Ethics and Organization Studies, 11 (2), 24-28.

Robbins, S.P., \& Coulter, M. (2007). Management (9th Ed.).London: PrenticeHall.

Rezaee, Z., Anvarpour, H., Sohrabipour, M., \& Negad, M.P. (2014). An examination of the relation between transformational leadership and organizational identity; a case study (petrochemical of Ilam province). Indian Journal of Fundamental and Applied Life Sciences, 4 (S4), 365-371.

Salajeghe, S., \& Ahmadzadeh, S. (2014). Survey the effect of transformational leadership on job attitudes of teachers with the mediating role of organizational identity, Bulletin of change management, the sixteenth year, 12, 73-90.

Turner, J.C., \& Reynolds, K.J. (2010). The Story of Social Identity. In: Postmes, T. and Branscombe, N., Eds., Rediscovering Social Identity: Core Sources, Psychology Press, New York, 13-32.

Warrilow, S. (2009). Transformational Leadership Theory - The 4 Key Components in Leading Change \& Managing Change. Retrieved August 17, 2018, from http://ezinearticles.com/?TransformationalLeadership-Theory---The-4-Key-Components-in-Leading-Change-andManaging-Change\&id=2755277. 